ISSN 0258-7122

Bangladesh J. Agril. Res. 35(3) : 453-463, September 2010

\title{
CHALLENGES OF POTATO CULTIVATION IN BANGLADESH AND DEVELOPING DIGITAL DATABASES OF POTATO
}

\author{
M. A. UDDIN $^{1}$, S. YASMIN ${ }^{2}$, M. L. RAHMAN ${ }^{3}$ \\ S. M. B. HOSSAIN ${ }^{4}$ AND R.U. CHOUDHURY ${ }^{5}$
}

\begin{abstract}
The study was conducted to build the union level digital database and maps of potato during 2008-09. Both primary and secondary data were used in the study. Data were collected from all blocks of four upazilas of four districts and farmers' level. Union, upazila, district, and country level digitized maps of Bangladesh were used in the programme. GIS, GPS, and MIS related IT were used in the study. Out of total cultivable land (1,00611 ha) in four upazilas, potato cultivated area and production were 27,414 ha and 3,32,424 t, respectively. Eighteen (18) varieties of potato were cultivated in the study areas, among them 13 were HYVs and 5 were local varieties. Out of $41 \mathrm{HYVs}$ of potato developed by BARI upto 2008, 13 were cultivated in the study areas. Maximum (89.7\%) area of HYV potato was covered by Diamant, Cardinal, Granola and Multa. At Chandina and Gozaria, potato area was only cultivated by HYVs. Shibganj and Pirganj shared 64 and 61\% potato areas, respectively under HYVs. Average potato yields of these upazilas and Gozaria were 14.34 and 24.36 t/ha, respectively, during 2008-09. Production cost and selling price were Tk. 8.73 and 11.56 per kg, respectively at the time of harvest in 2009. Benefit Cost Ratio (BCR) of potato was 1.32 and maximum was 1.37 at Pirganj. Besides adopting high yielding and hybrid varieties, management practices should be improved. It is possible to increase potato production by vertical and horizontal expression (Uddin, 2009).
\end{abstract}

Keywords: Union level digital database, maps, area, production, adoption, potato.

\section{Introduction}

Bangladesh is mainly an agro-based country. It is a thickly populated small country with an area of 14.48 million ha. According to an estimate by Bhuiyan et al., 2002, net cultivable land would decrease from 8.42 million ha in 2000 to 7.89 million ha in 2025 and population would increase from 127.22 million in 2000 to 168.96 million in 2025. The per capita net cultivable land would reduce from 0.066 ha in 2000 to 0.047 ha in 2025 (Bhuiyan et al., 2002). The population has doubled in the last 30 years despite a decline in the annual population growth rate from 2.26 in 1961 to 1.47 in 2004.

rrıncıраı scıenumc Uпıcer, curator, Training and Communication Wing, Bangladesh Agricultural Research Institute (BARI), Gazipur, ${ }^{5}$ Senior Scientific Officer, Plant Genetic Resources Centre, Bangladesh Agricultural Research Institute (BARI), Gazipur, Bangladesh. 
Potato is a staple food in the developed countries and which accounts for $37 \%$ of the total potato production in the world (FAO and CIP, 1995). Considering the trend of population growth and consequently the increased demand for food in the country and dwindling cultivable land area, the potato is likely to play a very important role in the future. Potato is a popular and important vegetable in Bangladesh. For the whole year, it is used as main vegetable. Potato growing areas of Bangladesh during 2008-09 are presented in the Map 1. Both Local and HYVs of potato considered for the study.

Using a global GIS data base of potato production, the average number of sprays was calculated by country. These averages were compared with estimates of current fungicide use. The results using Blitecast and Simcast were correlated but only Blitecast estimates correlated with observed data for developed countries.

The estimated number of sprays, whether from Blitecast or Simcast, did not correlate with the observed number of sprays in developing countries, and in a number of developing countries, the predicted optimal number of sprays was much higher than the actual number observed. In these countries, increased access to host resistance and fungicides could have a strong economic impact (Hijmans, 2000).

Projection of food (major cereal) requirement made by Bhuiyan et al. (2002) indicates that food requirement would increase from 20.96 million t from 10.71 million ha food cultivable area in 2000 to 27.81 million t from 10.17 million ha food cultivable area in 2025. This scenario shows that annually Bangladesh has to produce additional 0.274 million tons of food to maintain pace with the needs of population growth. The increased demand for food would have to meet with less land, less water, less labour and less pesticides due to increasing population and pressure on ever shrinking and degrading land and water resources.

Digitized maps of union, upazila, district, and country were used in the study. Block-wise information of area, production, yield, adoption, problems and solutions of potato were collected and documented in Arc View GIS programme. GPS technology was used at the time of data collection. Digital data base of potato will be able to give information of union-wise area, production, yield, adoption constraints etc. Time to time, this data base will be upgraded, so it will show us the latest information of potato. Digital database of it can help the user by showing the constraints and problems of potato cultivation in Bangladesh.

Bangladesh Agricultural Research Institute (BARI) is the largest multi-crop research institute. It conducts research activities on about 103 crops. Information of these crops and crop related factors are not easy to get. Therefore, documentation of information of all crops and crop related factors are very necessary. Per head cultivable land is about 12 decimals only. Each $\mathrm{cm}$ of land 
should be properly utilized. Considering the above factors, the present study on "Challenges of potato cultivation in Bangladesh and developing digital databases of potato" was selected with the following specific objectives:

1) Collection and documentation of information of potato for multidimensional use

2) Build, union, upazila, district and country maps of potato.

3) Study impact of BARI on the basis of adoption and area coverage by HYVs, of potato

4) Identify problems and suggested probable solutions for expansion of potato.

\section{Material and Method}

Data were collected from primary and secondary sources. Secondary sources were government and non-government organizations, such as Soil Resources Development Institute (SRDI), Bangladesh Bureau of Statistics (BBS), Food and Agriculture Organization (FAO), Department of Agricultural Extension (DAE) etc. Data were collected from the Sub-Assistant Agriculture Officer by direct interview with a set of questionnaires designed for this study. The questionnaires were modified according to expert comments, pre-tested, and then finalized after necessary corrections. For the present study, in case of farmers' fields, the simple random survey method was used and the investigator made multiple visits to collect the recent information. They asked questions in such a way as to create interest among the supervisors avoid boring. In case of any inconsistency, data were rechecked and corrected through repeated visits. The information were collected during the year 2009.

Different Softwares, such as Excel, SPSS, ArcView, Arclnfo etc. were used in the study. District, upazila, union level digitized boundary maps of Bangladesh were used.

A study was done by Hossain et al. (2005) as documentation and mapping of major tuber crops in Bangladesh: an application of GIS technology in 2005. Another study was done by Uddin et al. (2002) as documentation and mapping of major cereal crops: an application of GIS technology in 2002. 


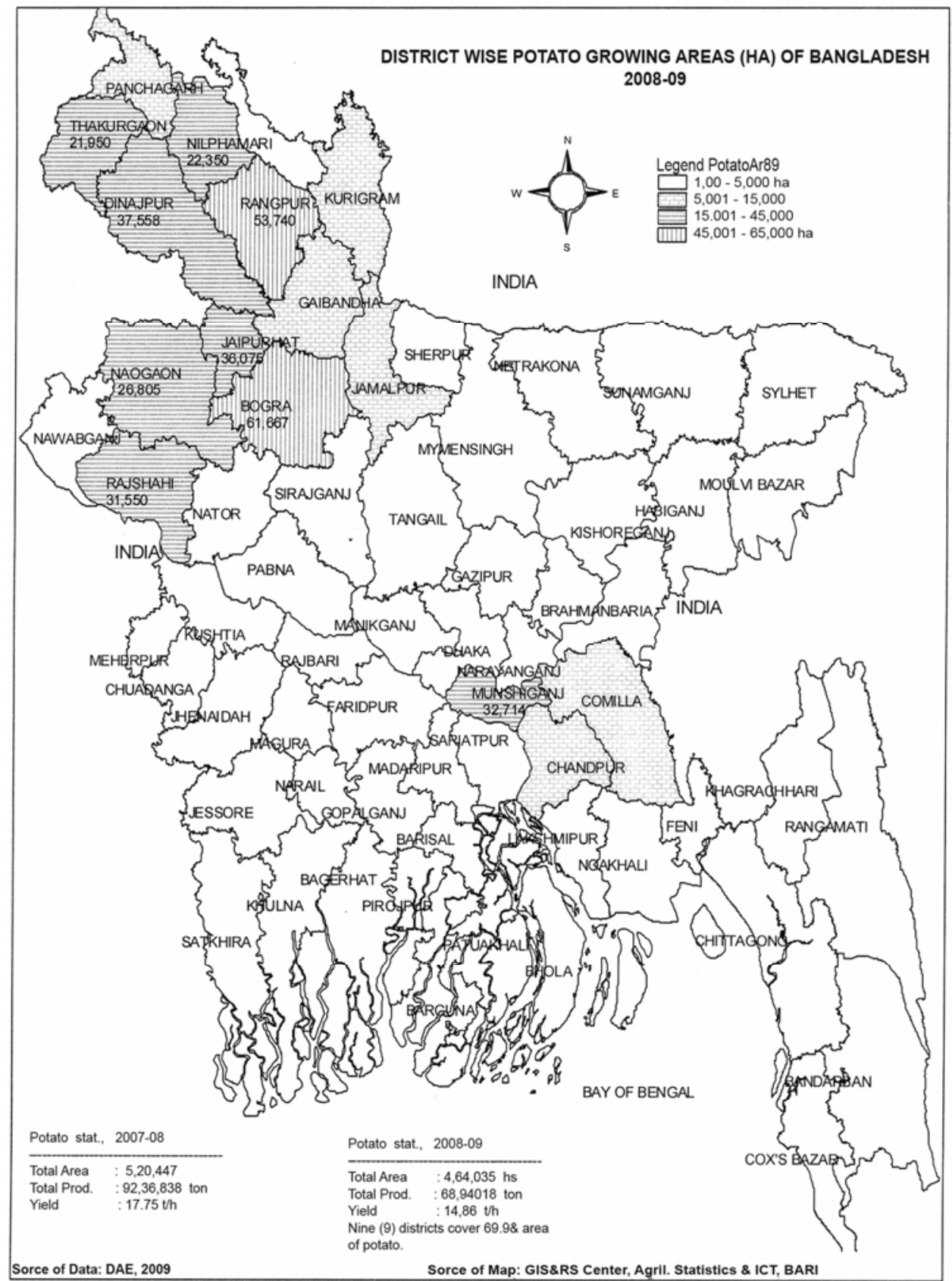

Map 1. Potato growing areas (ha) of Bangladesh, 2008-09 


\section{Results and Discussion}

This section can be divided into three sub sections:

Study area, Data and Problems of potato cultivation.

\section{Study area}

There were 1,38 blocks, 49 unions in four selected upazilas, Chandina,Gozaria, such as Shibganj, and Pirganj of Bangladesh (Table 1). Production related different agricultural information of these upazilas were noted.

Table 1. Blocks, unions and cultivable areas of four upazilas (Chandina, Gozaria, Shibganj and Pirganj) during 2008-09.

\begin{tabular}{l|l|l|l|l|l}
\hline \multicolumn{1}{c}{ Upazila } & $\begin{array}{c}\text { Chandina } \\
\text { (Comilla) }\end{array}$ & $\begin{array}{c}\text { Gozaria } \\
\text { (Munshiganj) }\end{array}$ & $\begin{array}{c}\text { Shibganj } \\
\text { (Bogra) }\end{array}$ & $\begin{array}{c}\text { Pirganj } \\
\text { (Rangpur) }\end{array}$ & Total \\
\hline Block & 49 & 24 & 30 & 35 & 138 \\
Union & 14 & 08 & 15 & 12 & 49 \\
Cultivable land (ha) & 14,351 & 7,336 & 26,160 & 52,764 & $1,00,611$ \\
\hline
\end{tabular}

Source: Field Survey, 2009.

Data of potato of all the blocks of the upazila were collected and documented. Total cultivable land in 4 upazilas was 1,00,611 ha in which Pirganj alone contained 52,764 ha (50\%).

Table 2. Area, production and yield data of potato at Chandina, Gozaria, Shibganj and Pirganj of Bangladesh during 2008-09.

\begin{tabular}{|c|c|c|c|c|c|c|c|}
\hline Area & $\begin{array}{l}\text { Area } \\
\text { (ha) }\end{array}$ & $\begin{array}{c}\text { Production } \\
\text { (t) }\end{array}$ & $\begin{array}{l}\text { Yield } \\
\text { (t/ha) }\end{array}$ & $\begin{array}{c}\text { Price } \\
(\mathrm{Tk} / \mathrm{kg})\end{array}$ & \begin{tabular}{|c} 
Cost of \\
production \\
$(\mathrm{Tk} / \mathrm{kg})$
\end{tabular} & $\begin{array}{c}\text { Benefit/ } \\
\text { Profit } \\
(\mathrm{Tk} / \mathrm{kg})\end{array}$ & BCR \\
\hline $\begin{array}{l}\text { Chandina } \\
\text { (Comilla) }\end{array}$ & 3,006 & 47,880 & 15.82 & 11.63 & 8.9 & 2.73 & 1.31 \\
\hline $\begin{array}{l}\text { Gozaria } \\
\text { (Munshiganj) }\end{array}$ & 2,495 & 60,781 & 24.36 & 11.64 & 9.50 & 2.14 & 1.23 \\
\hline $\begin{array}{l}\text { Shibganj } \\
\text { (Bogra) }\end{array}$ & 17,597 & $1,84,523$ & $\begin{array}{l}12.69 \text { (HYV) } \\
7.12 \text { (Local) } \\
10.50 \text { (both) }\end{array}$ & $\begin{array}{l}11.20 \\
14.50\end{array}$ & $\begin{array}{l}8.28 \\
12.00\end{array}$ & $\begin{array}{l}2.92 \\
2.50\end{array}$ & $\begin{array}{l}1.35 \\
1.21\end{array}$ \\
\hline $\begin{array}{l}\text { Pirganj } \\
\text { (Rangpur) }\end{array}$ & 4,316 & 39,240 & $\begin{array}{l}12.25 \text { (HYV) } \\
7.50 \text { (Local) } \\
9.09 \text { (both) }\end{array}$ & $\begin{array}{l}11.75 \\
15.00\end{array}$ & $\begin{array}{l}8.60 \\
11.93\end{array}$ & $\begin{array}{l}3.15 \\
1.29\end{array}$ & $\begin{array}{l}1.37 \\
1.26\end{array}$ \\
\hline Total/Average & 27,414 & $3,32,424$ & $\begin{array}{l}16.34(\mathrm{H}) \\
14.34(\mathrm{~B})\end{array}$ & 11.56 & 8.73 & 2.83 & 1.32 \\
\hline
\end{tabular}

Source: Field Survey, 2009. 
Total cultivated area of potato in the study areas was 27,414 ha and the maximum was 17,597 ha at Shibganj. Total production was 3,32,424 t, whereas the maximum was 1,84,523 $t$ at Shibganj and the minimum 39,240 $t$ at Pirganj. Average yield of potato was 14.34 t/ha for these upazilas in 2009 (Table 2). But average potato yield was 22.25 t/ha for both the locations Comilla and Munshiganj in 2008 (Uddin, 2008). Average potao yield of these locations (Comilla and Munshiganj) was $20.50 \mathrm{t} / \mathrm{ha}$, whereas individual average yields at Comilla and Munshiganj were 16.23 and 24.78 t/ha, respectively, in 2005 (Uddin, 2009). Due to late blight yield was very low in the northern part of Bangladesh in 2009.

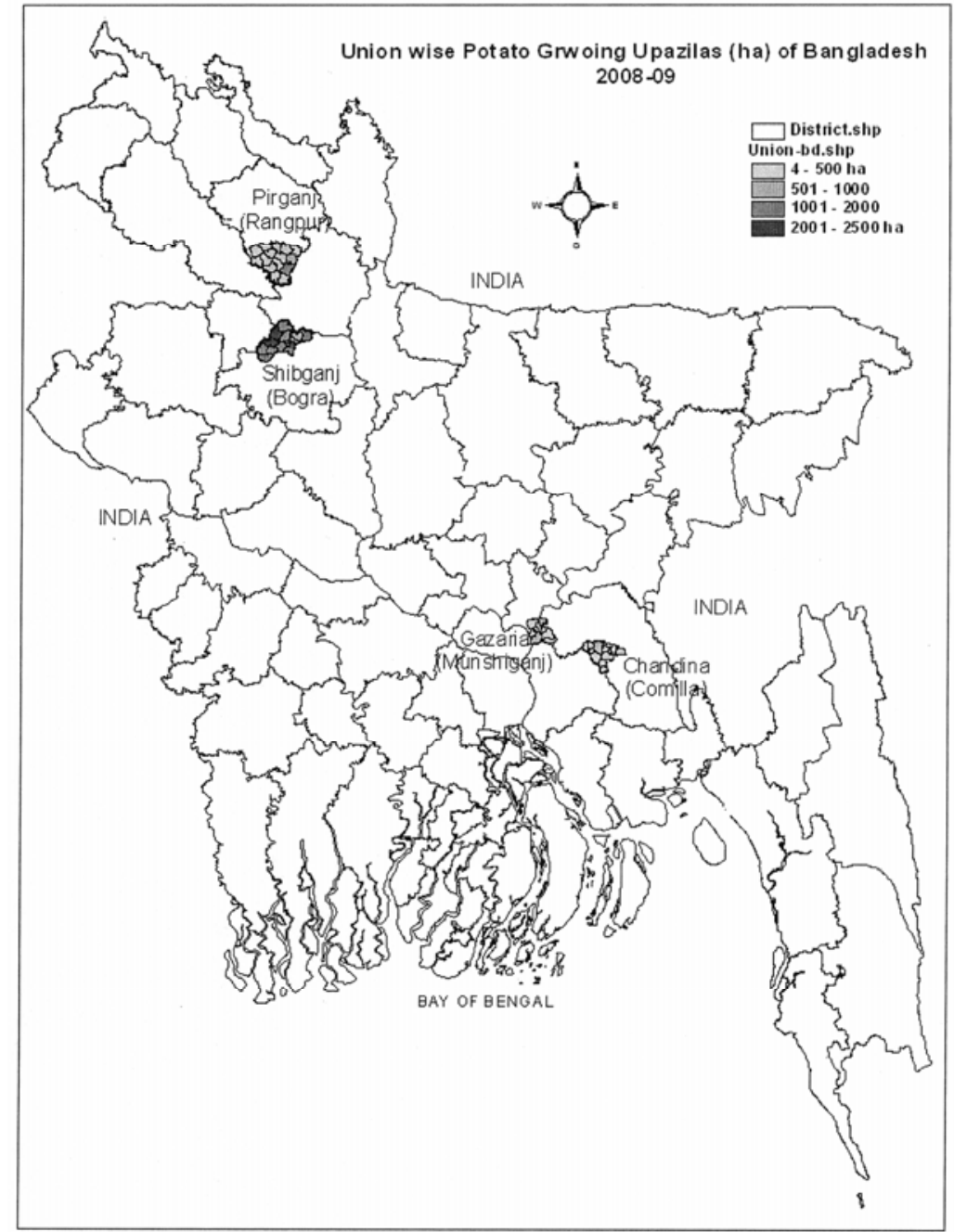

Source : Field Survey, 2009

Map 2. Union-wise potato growing upazilas (ha) of Bangladesh, 2008-09. 
Area and production data of potato were sorted for ranking and categorized for mapping. Yield of potato of different unions and upazilas were calculated by applying SQL quarry option of GIS. Interpolation option was used for estimate internal missing data (Map 2, Table 2).

Adoption status and area coverage by the HYVs and local varieties of potato in the study areas are shown in Table 3 and 4.

Table 3. Adoption status and variety-wise area coverage of HYVs of potato during 2008-09.

\begin{tabular}{l|l|l|l|l|l|l}
\hline \multicolumn{1}{c}{ Variety } & $\begin{array}{c}\text { Chandina } \\
\text { (ha) }\end{array}$ & $\begin{array}{c}\text { Gozaria } \\
\text { (ha) }\end{array}$ & $\begin{array}{c}\text { Shibganj } \\
\text { (ha) }\end{array}$ & $\begin{array}{c}\text { Pirganj } \\
\text { (ha) }\end{array}$ & Total & $\begin{array}{c}\text { Percent- } \\
\text { age }\end{array}$ \\
\hline Diamant & $1,904(63)$ & $1,593(64)$ & $360(2)$ & $593(13.7)$ & 4,450 & 23.0 \\
Cardinal & $10(0.4)$ & $5(0.2)$ & $2,268(13)$ & $873(20)$ & 3,136 & 16.3 \\
Granola & - & $304(12.2)$ & $7,420(43)$ & $707(16.3)$ & 8,431 & 43.6 \\
Multa & $1,020(34)$ & $130(5.2)$ & $170(1)$ & - & 1,320 & 6.8 \\
Patrones & $2(0.1)$ & $68(2.7)$ & $195(1)$ & $60(1.4)$ & 325 & 1.7 \\
Origo & $42(1.5)$ & - & - & - & 42 & 0.2 \\
Binella & - & $372(15)$ & - & - & 372 & 1.4 \\
Heera & - & - & $60(0.3)$ & - & 60 & 0.3 \\
Asterix & - & - & $70(0.4)$ & - & 70 & 0.4 \\
Elvira & - & - & $427(2.5)$ & - & 427 & 2.2 \\
Ultra & - & $18(0.7)$ & - & - & 18 & 0.1 \\
Provento & $28(1)$ & - & - & - & 28 & 0.1 \\
Kufri Sinduri & - & - & - & $425(9.8)$ & 425 & 2.2 \\
Others & - & $5(0.2)$ & $210(1.2)$ & - & 215 & 1.2 \\
\hline Total & $3,006(100)$ & $2,495(100)$ & $11,180(65)$ & $2,658(61)$ & $19,339(71 \%)$ & 100 \\
\hline
\end{tabular}

Source: Field Survey, 2009, * Values in bracket are percentage data

Out of 27,414 ha, maximum (19,339 ha) was cultivated by HYVs and the rest 8075 ha by local varieties. Among 19,339 ha HYVs potato, 3006 ha (100\%) and 2495 ha (100\%) were cultivated by HYVs at Chandina and Gozaria, respectively. However, 11,180 ha (65\%) and 2658 ha (61\%) were cultivated by HYVs at Shibganj and Pirganj, respectively, and the rest by local varieties. Out of 3006 ha of HYV potato, 1904 ha (63\%) and 1,020 (34\%) were cultivated by Dimant and Multa, respectively, and the rest by others at Chandina. At Gozaria, out of 2495 ha of HYV potato, 1593 ha (64\%), 372 ha (15\%), and 304 ha (12.2\%) were cultivated by Diamant, Binella, and Granola, respectively. At Shibganj, out of 11,180 ha HYV potato, 7420 ha (43\%) and 2268 ha (13\%) were cultivated by Granola and Cardinal, respectively, and the rest $9 \%$ by other HYVs (Table 3). At Pirganj, among 2658 ha (61\%) HYVs potato, 50\% was cultivated by Cardinal, Granola, and Diamant and the rest $11 \%$ by others (Table 3). Table 4 shows that at Shibganj, out of 17,597 ha (100\%) potato area, 6,417 ha (35\%) was cultivated by local varieties. 
Table 4. Adoption status and area coverage by different local varieties of potato during 2008- 09.

\begin{tabular}{l|l|l|l|l|l|l}
\hline \multicolumn{1}{c}{ Variety } & Chandina & Gozaria & \multicolumn{1}{c}{ Shibganj } & Pirganj & Total & Percentage \\
\hline Shilbilati & - & - & - & $103(0.7)$ & 103 & 1.3 \\
Indurkani & - & - & - & $566(13)$ & 566 & 7.0 \\
Lal pakri & - & - & $135(0.8)$ & $280(6.5)$ & 415 & 5.1 \\
Pakri & - & - & $2350(13.7)$ & $20(0.5)$ & 2,370 & 29.3 \\
Surjamukhi & - & - & $325(1.9)$ & $320(7.4)$ & 645 & 8.0 \\
Others & - & - & $3607(18.4)$ & $369(10.8)$ & 3,976 & 49.2 \\
\hline Total & & - & $6,417(35)$ & $1,658(39)$ & $8,075(29 \%)$ & 100 \\
Grand total & $3,006(100)$ & $2,495(100)$ & $17,597(100)$ & $4,316(100)$ & $27,414(100 \%)$
\end{tabular}

Source: Field Survey, 2009. * Value in bracket indicates percentage data.

Among the local varieties, 135 ha (0.8\%), 2350 ha (3.7\%), and 325 ha (1.9\%) were cultivated by Lalpakri, Pakri, Surjamukhi, respectively, and the rest by others. Similary for Pirganj, Rangpur, out of 1658 ha (39\%) local varieties, 566 ha (13\%), 320 ha $(7.4 \%), 103$ ha $(0.7 \%), 280$ ha $(6.5 \%), 20$ ha $(0.5 \%)$ were cultivated by Indurkani, Surjamukhi, Shilbilati, Lalpakri, Pakri, respectively, and the rest by others (Table 4).

\section{Problems of potato cultivation and suggestions}

Problems of potato cultivation are given below:

Table 5. The major problems of farmers for HYV potato cultivation during 2008-2009.

\begin{tabular}{l|l|l|l|l}
\hline Items & Yes & $\begin{array}{l}\text { Percentage } \\
\text { and Ranked }\end{array}$ & Mean & Std \\
\hline 1. Non-availability of quality seeds timely & 26 & $11.94(3)$ & & \\
2. High price of fertilizer & 28 & $12.78(2)$ & & \\
3. Lack of irrigation facilities and high cost & 21 & $9.86(5)$ & & \\
4. Lack of credit facilities & 27 & $12.50(2)$ & & \\
5. Insect pest and disease problem & 29 & $13.33(1)$ & 21.60 & 7.29 \\
6. Labour crisis & 5 & $2.22(8)$ & & \\
7. Lack of storage facilities & 15 & $6.81(7)$ & \\
8. Marketing problem & 19 & $8.89(6)$ & \\
9. Lack of cash capital & 23 & $10.42(4)$ & & \\
10. Others (specify if any) & 24 & $11.25(3)$ & & \\
& 216 & 100 & \\
\hline
\end{tabular}

Source: Farmers’ Field Survey, 2009

Among the problems of potato cultivation (Table 5), rank 1st was insect-pest and disease, rank 2 was high price of fertilizer, 3rd non-availability of quality seeds timely and so on for others during 2008-09. Similar results are also shown elsewhere (BARI Annual Report, 2009). 
Problems of the potato growers during 2000-2001 were in order of rank 1. Lack of quality seed, 2. Lack of cash money, 3. Higher price of inputs, 4.Lack of storage facility, 5. Lower price of product at harvesting period, and 6. Lack of adequate labour in the production period (Rashid et al., 2001).

Suggestions to overcome the constraints and to increase the production of potato

Table 6. Suggestions to over-come the constraints for potato cultivation, 2008-2009.

\begin{tabular}{l|l|l|l|l}
\hline Items & Yes & $\begin{array}{l}\text { Percentage } \\
\text { and Ranked }\end{array}$ & Mean & Std \\
\hline 1. Good Seed & 10 & $20(2)$ & & \\
2. Fertilizer in cheaper rate & 14 & $28(1)$ & & \\
3. New HYV & 14 & $28(1)$ & & \\
4. Training & 3 & $6(3)$ & \\
5. Withdrawal of old seeds & 1 & $2(6)$ & & \\
6. Powerful insecticide & 2 & $4(4)$ & \\
7. Timely availability of MV of needed crops & 1 & $2(6)$ & \\
8. Government purchase centre & 1 & $2(6)$ & \\
9. Price should be increased at the time of harvest & 2 & $4(5)$ & \\
10. High quality fertilizer and insecticide & 1 & $2(6)$ & & \\
11. Cultivate self land & 1 & $2(6)$ & & \\
& 50 & 100 & & \\
\hline
\end{tabular}

Source: Farmers’ Field Survey, 2009.

Suggestions and opinions, which were stated by the farmers to overcome the problems and increase, the potato production indicated that new HYV (rank 1st), Fertilizer in cheaper rate (rank 1st), good seed (rank $2^{\text {nd }}$ ) and training (rank 3rd) were important (Table 6).

\section{Recommendations}

Based on the results of the study, the following recommendations are furnished.

1. SAAO should be encouraged to get correct and accurate information of potato.

2. In each upazila, internet facilities should be set up and by using internet, necessary data to be collected.

3. One agricultural graduate needs to be appointed in each union for giving necessary guidance to the farmers for proper adoption of HYVs and utilization of quality seeds approved by BARI.

4. One training institute in each division for the training of farmers and SAAO on modern agriculture needs to be established. 
5. Like India, an academy for agricultural research management is to be established in Bangladesh for the purpose of developing managerial capabilities of the scientists.

\section{Further research strategies for the development of agriculture in Bangladesh}

1. It is a system of developed programme that indicates the distribution of data base structure to the Upzila Agriculture Officer to entry block level potato cultivated data. These data were sent to the Head Office of BARI, Gazipur by internet. Data of all other crops may be sent in this way.

2. This programme will be extended from union to mouza level for data collection and documentation.

3. It is a census data not survey data of potato, so it is a measure of whole population. This type of such data are needed for GIS map.

\section{Conclusion}

Based on the findings of the study and discussions with the farmers and SAAOs, the following conclusions were drawn:

1. Yield of potato was low in the northern part of the country due to late blight during 2008-9.

2. Due to use of low quality seed, yield of potato in Comilla area was low in the same period.

3. Cost of productions was higher but price of potato was lower at the time of harvest. So, farmers became looser.

\section{References}

BARI Annual Report. 2009. Training and Communication Wing, Gazipur, pp. 29-35

Bhuiyan, N. I., D. N. R. Paul and M. A. Jabber. 2002. Feeding the extra millions by 2025: Challenges for rice research and extension in Bangladesh. A Keynote Paper Presented at National Workshop on Rice Research and Extension-2002. Bangladesh Rice Research Institute, Gazipur, 29-31 January 2002.

DAE. 2009. Department of Agriculture Extension, Ministry of Agriculture, Khamarbari, Farm Gate, Dhaka.

Hijmans, R.J., G. A. Forbes and T. S. Walker. 2000. Estimating the global severity of potato late blight with GIS-linked disease forecast models, J. Plant Pathology 49: 697-705 International Potato Center (CIP), Apartado 1558, Lima 12, Peru.

Hossain, M.I , M.A. Hossain, M. I. Hossain and M.S. Islam.2005. Annual Report of BARI 2004-2005, Agricultural Economics Division, Gazipur, pp. 149-159

FAO and CIP. 1995. Potatoes in the 1990s: Situation and prospects of the world potato economy. FAO, Rome (Italy), 39pp. 
Rashid, M. A. 2001. Crop cultivation practices: Input-out put relationship of major crops in Bangladesh. Agricultural Research Management Project, BARC, 2001.

Uddin, M. A. 2008. Management of agricultural research organizations with special reference to utilization of high yielding varieties in Bangladesh (Ph. D. thesis), Islamic University, Kushtia, Bangladesh.

Uddin, M. A., Q.M. Alam and M.A Baset. 2009. Potato for food security in Bangladesh, Int. J. Sustain. Crop Prod 2004-2011 Green World Foundation (GWF)- Canada.

Annual Report. 2001-2002, Agricultural Economics Division, Gazipur. pp 175-182. 